\title{
Sources of Microbrewery Competitiveness in the Czech Republic
}

\author{
T. Maier
}

Faculty of Economics and Management, Czech University of Life Sciences Prague, Czech Republic

\begin{abstract}
This article aims to determine the reasons for the number of microbreweries increasing in the Czech Republic. The analysis compares various (micro)brewing industry indicators in selected traditional beerdrinking countries. The research questions are focused on relations among number of microbreweries and demographic aspects, market concentration aspects and some other beer market indicators. Furthermore, there were made simulation - for which conditions will be in the Czech Republic 400, 500 and 1000 microbreweries. Statistically significant dependency on the number of microbreweries are beer market concentration (Gini index), the percentage of the total population made up of the 25 - 39 years age group, and the share of domestic beer consumption in cans. Since the beginning of Economic crisis the number of Czech microbreweries has been increasing exponentially and the results suggest that the microbrewery boom will have been continuing.
\end{abstract}

\section{Keywords}

Microbrewery, craft brewery, demography, market concentration, Plato, beer.

Maier, T. (2016) "Sources of Microbrewery Competitiveness in the Czech Republic", AGRIS on-line Papers in Economics and Informatics, Vol. 8, No. 4, pp. 97 - 110. ISSN 1804-1930. DOI 10.7160/aol.2016.080409.

\section{Introduction}

The production of fermented drinks made from cereals began soon after cereal cultivation. The beer hopping process is much younger. The cultivation of hop began around A.D. 859 (Behre, 1998). Thanks to the low amount of alcohol, the beer (or rather fermented drink made from cereals) became a social drink. Beer consumption has a powerful cultural role in many societies (Carroll, Swaminathan, 2000; Kirkby, 2003; McAllister, 2003, 2006), and in the Czech Republic especially it is a very important social phenomenon and very often pubs in small villages are the the sole centre of social life. In the Czech lands, a different technique is historically used for beer production. The decoction technique is much better suited for the Czech type of beer as during its production a number of agents are produced which positively affect the sensory value of the beer (Kryl et al., 2012). The first commercial breweries emerged at the turn of the $12^{\text {th }}$ and $13^{\text {th }}$ century (Strizencova, 2014). The microbreweries segment is historically a phenomenon of a postindustrial era. Before this era, all breweries had many technological limits and they had very limited opportunities to grow.

The Czech brewing industry has a number of peculiarities when compared to other well developed beer-producing countries. The first difference compared to the other main beerproducing countries is a remarkably high level of (main) product homogeneity. In 1994, $97.2 \%$ of beer produced was pilsner and $2.8 \%$ was dark lager (CBAMA) in Czech breweries. Porter (1980) has identified three generic strategies available to firms: low cost, differentiation, and focus. Because of the homogenous market, there were perfect condition for using second strategy for differentiation in the Czech Republic that in the first half of $90^{\prime} \mathrm{s}$. Moreover, there was no production of any top fermented beer. Porter (in frame of "focus") means that the firm should develop the ability to serve a particular target customer group very well (often at the expense of other potential customer groups) and this is strategy, which the microbreweries use mainly for younger consumers (demographic aspects). The only strategy which is not usable for microbreweries is the low cost strategy. Consider the American beer brewing industry - its market was virtually stagnant before the microbrewery movement. Specialty brewers tapped new beer business, bringing in new customers for as much as half of their markets (Backus, 1999). The number of breweries fell sharply during the communist era. Maye (2012) came to the conclusion that if a particular town has one 
brewery then the inhabitants will not experience much variety. Especially at the beginning of communist era, many smaller breweries were closed and during the whole communist era the market was managed by the state on the basis of regionalism.

The Czech beer market has been changing very slowly, with dark beer making up $2.62 \%$ of total production and top fermented beer making up $0.23 \%$ of total production within industrial breweries (CBAMA) in the Czech Republic in 2015. The USA saw a very similar situation in the past. In 1970 s there were no specialty brewers. In 2003, specialty brewers commanded a $3.3 \%$ share of domestic beer production and a $2.9 \%$ share of total U.S. consumption (Tremblay, 2005).

As such, the Czech beer market is generally characterized by a high level of product homogeneity, but on for microbreweries the situation is different with the products of microbreweries characterized by considerably high product heterogeneity ${ }^{1}$. It is very difficult to quantify the market share of microbreweries, because in the Czech Republic it is not obligatory for the breweries to publish beer production volumes. But if we take a microbrewery to mean a brewery with annual production of less than $10000 \mathrm{hl}$, then according to the Customs Office (responsible for excise tax collection) we can deduce that the market share of microbreweries on domestic consumption was approximately $1.7 \%$ in 2015. In 1994, 16 microbreweries were operating, and as such the market share of microbreweries was unimportant. Figure 1 shows the Czech microbreweries market share over 10 years (2006 - 2015). In 2009, the microbrewery market

\footnotetext{
The product heterogeneity means that the production units (microbreweries) produce various kinds of beers (like ale, stout porter, weitzen etc.) instead of one kind (like lager).
}

share has started to accelerate. The average chain index value for the above mentioned period is $113.9 \%$, which means it is very progressive sector, especially since domestic consumption of beer decreased over the $2006-2015$ period. The index $2015 / 2006$ is $790 \%$, so it means that in 2015 was the market share of microbreweries by $690 \%$ higher than in 2006 .

It is possible to make a comparison on the basis of the number of microbreweries per 1 mil. inhabitants indicator between various (selected) states. The results are given in Table 1. In 2014, the Czech Republic was in second position, with Switzerland in first position. In the Czech case, however, we can see a high acceleration in this indicator in the $2011-2014$ period. All the values in the Table 1 are rather indicative however, because there are various definitions and various conditions pertinent to each of above mentioned states.

\begin{tabular}{|l|r|r|r|r|}
\hline & 2011 & \multicolumn{1}{|c|}{2012} & \multicolumn{1}{|c|}{2013} & 2014 \\
\hline USA & 6.2 & 7.5 & 9.0 & 11.2 \\
\hline Czech Republic & 11.4 & 13.6 & 18.2 & 22.0 \\
\hline Austria & 11.4 & 10.8 & 12.8 & 12.8 \\
\hline Germany & 8.1 & 8.2 & 6.9 & 8.4 \\
\hline United Kingdom & 13.9 & 19.4 & 22.3 & 21.9 \\
\hline Switzerland & 38.2 & 40.1 & 44.3 & 53.7 \\
\hline Spain & 1.5 & 2.5 & 4.4 & 6.8 \\
\hline Italy & 5.5 & 6.7 & 8.1 & 9.6 \\
\hline Ireland & - & 3.2 & 5.0 & 6.9 \\
\hline
\end{tabular}

Sources: Brewers Association, World Bank, Swiss Customs Administration and Brewers of Europe

Table 1: Number of microbreweries per 1 mil. inhabitants in selected states.

In the United States the term "craft brewery" is more frequently used, while the term "microbrewery" is more frequently used in the EU. In the United

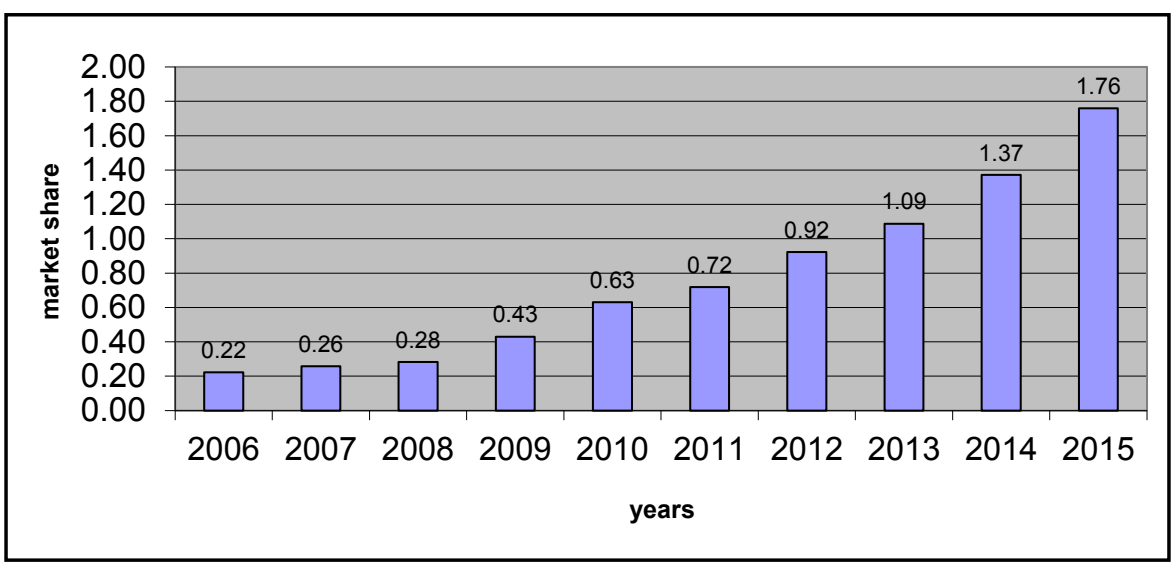

Source: Customs Administration of the Czech Republic

Figure 1: Czech microbreweries market share development in $2006-2015$ (\%). 
States, according to US Brewers Association, the category "craft brewery" consists of four groups:

1. Microbrewery: A brewery that produces less than 15,000 barrels $(17,600$ hectoliters) of beer per year with 75 percent or more of its beer sold off-site.

2. Brewpub: A restaurant-brewery that sells 25 percent or more of its beer on site. The beer is brewed primarily for sale in the restaurant and bar.

3. Contract Brewing Company: A business that hires another brewery to produce its beer. It can also be a brewery that hires another brewery to produce additional beer.

4. Regional Craft Brewery: An independent regional brewery with a majority of volume in "traditional" or "innovative" beer(s). (Brewers Association)

Wells (2016) noted in regard to this problem that the conflation of brewpubs and microbreweries reflects some ambiguities in the data and the definitions of these activities. Brewpubs are businesses that brew and sell their beer on the premises; microbreweries on the other hand are small-scale brewers (and scale here is open to some debate) that may sell on the premises but may also distribute their product to other retailers, sometimes over long distances. Both categories are sometimes also known as craft brewers or artisanal brewers. Bower \& Cox (2012) and Sandberg (2010) add one aspect that is of interest is that beer can be made at almost any scale, from the household level through to huge multinational combines running vast centralised production complexes.

The fuzziest definition is that of "regional craft brewery"; this category can also cover big breweries like the Boston Beer Company. According to its Annual Report, this company produced $6677466 \mathrm{hl}$ in the 2015 fiscal year, which represents one third of total annual beer production in the Czech Republic. In 1980s, the Boston Beer Company entered the sector like any typical small microbrewery, and boosted by the large US market it has grown very strongly. But for the category "craft brewery", the number of regional craft breweries is not so important; in the USA a total of 4225 craft breweries were operating in 2015, including 178 regional craft breweries (Brewers Association), representing $4.2 \%$ of the total.

In the EU, the regional craft breweries typical for the US are almost non-existent, there being two reasons for this situation. In EU states, beer never changed into such an homogenous product as it did in the USA in the second half of 20th century. The second reason is that the national markets in EU are much smaller, such that regional craft breweries do not have such good conditions for growing, being more limited.

The most intensive microbrewery state in the whole world is Switzerland; according to Swiss Customs Administration, in 2014 there were 53.7 microbreweries operating per million inhabitants. This is more than 2.4 times the figure in the Czech Republic, which is in second position. According data from the Swiss Federal Customs Administration FCA, in Switzerland in 2014 there were 483 breweries and one year later there were 623 breweries. It can be supposed that these 140 new breweries over the course of 2015 are mainly (or only) microbreweries. The reasons for this situation can be historical, as Switzerland is a traditional beer-drinking country, and also that the purchasing power of Swiss consumers is one of the highest in the world. Meanwhile, Switzerland does not have a progressive excise tax system for beer. In Switzerland, compared to the Czech Republic, there are only three excise tax brackets which depend on ${ }^{\circ}$ Plato, while in the Czech Republic the amount of tax depends on each additional ${ }^{\circ}$ Plato. Let's give an example. A brewery with annual production of less than $10,000 \mathrm{hl}$ pays excise tax of 8 EUR for $12-12.99^{\circ}$ Plato in the Czech Republic, while in Switzerland it would pay 26.3 EUR. Both these values are calculated per $1 \mathrm{hl}$ of beer. The excise taxes are additional costs for brewers, so it represents a restriction for them. On the other hand, taxes on alcohol contribute to the state's exchequer (Castiglione et al., 2011). Ellis, V. and Bosworth, G. (2015) indicate that the number of microbreweries in the UK has more than doubled since the start of the millennium. Compared to the United Kingdom, there has been more expansion in the Czech Republic.

The Czech excise beer tax is shown in Table 2 . The progressive beer excise tax system was established in 1995 and was inspired by the German tax system. This system helps smaller producers to stay or to enter the market. In 1995, only approximately 20 microbreweries were operating in the Czech Republic, and as such the lobby comprised mainly smaller industrial breweries.

Another particular of the Czech beer market is that it is almost closed to imports. Czech consumers are very conservative and they do not usually prefer foreign brands. The figure 2 shows the share 


\begin{tabular}{|l|c|c|c|c|c|c|}
\hline \multirow{2}{*}{ Year } & Basic rate & \multicolumn{5}{|c|}{ Reduced rate (EUR) for annual production up to } \\
\cline { 3 - 7 } & $($ EUR) & 10,000 & 50,000 & 100,000 & 150,000 & 200,000 \\
\hline 2009 & 0.907 & 0.453 & 0.544 & 0.635 & 0.725 & 0.816 \\
\hline 2010 and further years & 1.209 & 0.605 & 0.725 & 0.846 & 0.967 & 1.088 \\
\hline
\end{tabular}

Note: Exchange rate of 31/12/2009

Source: Act No. 353/2003 of the Legal Code

Table 2: Beer excise tax rates in the Czech Republic.

of Czech beer import and export based on data from the Czech Statistical Office for the period 1999 - 2015. In the observed period we can see that export grew over almost the whole time, although in the economic crisis period tone can detect stagnation or very slight decrease. 2015 shows historically the highest export, with more than $20 \%$ of domestic production exported for the first time the Czech history.

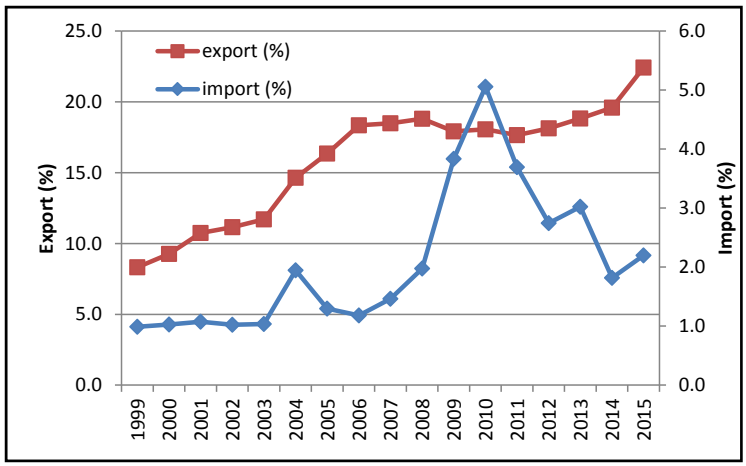

Source: Czech Statistical Office, Customs Administration of the Czech Republic

Figure 2: Share of Czech beer import and export.

Import was very low compared to export, and lower than $2 \%$ of domestic beer consumption until 2008. Then it started to increase, but the main reason here was a sudden change in consumer habits, with consumers starting to demand beer in plastic bottles, a technology which in 2009 was only used in one small Czech brewery, Nová Paka. As such, the large brewery companies imported beer in plastic bottles. Later, the breweries built their own technology for plastic bottles such that in 2014 import was once again less than $2 \%$ of domestic consumption.

If we compare these indicators with the other selected EU countries (Table 3), we can see that all other states have higher values of import, the lowest being in Austria (6.9\%) and the highest in Ireland (49.8\%), but this value is decreasing.

A Relatively large change in terms of export is indicated in Slovakia from 2010 compared to the previous year. The export value went from $0.5 \%$ to $8.7 \%$. The reason for this is theabovementioned plastic bottles. In 2010, Heineken International ( $3^{\text {rd }}$ position on the Czech beer market, leader in Slovakia) started with heavy exports of beer in plastic bottles from Slovakia to the Czech Republic, because in Slovakia this company had plastic beer bottle technology.

Another strong specific indicator compared to other well developed beer-drinking states is the Czech Republic's highest consumption per capita in the whole world. Within the Czechoslovak federation (before 1993) the Czech Republic reached the top global position in 1970, but in the past Czechoslovakia had a lower consumption than Western Germany. This has changed with the independence of the Czech Republic. But beer consumption volume is not mainly determined in accordance with particular states, but rather by habits within particular regions. The region with the highest beer consumption per capita is Bavaria excepting its southwest part, Bohemia except Prague and the western part of Austria. It can be supposed that in this region the per capita beer consumption may be around 170 liters. The per capita beer consumption for selected states is shown in Table 4.

In the Table 4 it is possible to detect the strong influence of the economic crisis on the Czech beer sector. Year-on-year $(2010 / 2009)$ the per capita consumption decreased by $10 \%$, while in all the other states the affect of beer crisis was not so strong. Generally, we can make the statement that in all traditional beer-drinking states, per capita beer consumption has been decreasing.

From the above discussed, we can deduce that the microbrewery boom in the Czech Republic is a society-wide phenomenon, and thus we need to find the reasons behind this boom and in particular to find the sources of Czech microbrewery competitiveness. The aims of the paper are:

1. To quantify the number of all microbreweries over the period 1991 - 2015. Because there are no official statistics in the Czech Republic for this indicator 


\begin{tabular}{|l|r|r|r|r|r|r|}
\hline & 2009 & 2010 & 2011 & 2012 & 2013 & 2014 \\
\hline Germany import & 7.3 & 8.5 & 8.8 & 8.4 & 7.3 & 7.7 \\
\hline Germany export & 14.3 & 15.8 & 16.7 & 16.6 & 16.0 & 16.2 \\
\hline Belgium import & 10.3 & 11.0 & 12.8 & 14.1 & 12.7 & 13.7 \\
\hline Belgium export & 56.8 & 58.5 & 59.7 & 62.3 & 61.1 & 61.6 \\
\hline Austria import & 6.9 & 6.9 & 7.4 & 7.5 & 6.9 & 7.4 \\
\hline Austria export & 7.7 & 8.0 & 8.0 & 7.9 & 9.1 & 9.9 \\
\hline Slovakia import & 22.4 & 25.3 & 25.7 & 26.7 & 29.9 & 31.2 \\
\hline Slovakia export & 0.5 & 8.7 & 4.3 & 5.3 & 10.1 & 6.5 \\
\hline United Kingdom import & 16.5 & 17.6 & 18.7 & 20.5 & 20.7 & 19.5 \\
\hline United Kingdom export & 10.5 & 10.2 & 9.9 & 13.9 & 15.6 & 12.7 \\
\hline Ireland import & & & & 34.3 & 29.2 & 29.8 \\
\hline Ireland Export & & & & 42.9 & 49.8 & 38.5 \\
\hline
\end{tabular}

Sources: Brewers of Europe

Table 3: Share of import and export for selected EU countries.

\begin{tabular}{|l|r|r|r|r|r|r|}
\hline State/Year & 2009 & 2010 & 2011 & 2012 & 2013 & 2014 \\
\hline Czech Republic & 159 & 143 & 142 & 147 & 144 & 144 \\
\hline Germany & 110 & 107 & 107 & 108 & 107 & 107 \\
\hline Austria & 107 & 106 & 108 & 108 & 106 & 104 \\
\hline Ireland & 91 & 90 & 86 & 86 & 79 & 81 \\
\hline Belgium & 81 & 78 & 78 & 74 & 72 & 72 \\
\hline United Kingdom & 71 & 69 & 67 & 67 & 66 & 68 \\
\hline USA & - & 78 & 77 & 78 & 76 & 76 \\
\hline
\end{tabular}

Source: Statista, Inc., Brewers of Europe

Table 4: Per capita beer consumption (1).

and this variable is required to undertake the research further (aim), it is necessary first of all to quantify (or estimate) these values.

2. To determine main external reasons for microbrewery foundation.

In particular, the paper addresses following research questions:

i. Is there any statistically significant relationship between number of microbreweries and selected demographical aspects? It can be supposed that the total population value can influence the number of microbreweries; and furthermore certain selected age bracket may also influence it. Microbreweries usually focus their production on (non-conservative) consumers, and thus this aspect may be a very important source of Czech microbrewery competitiveness.

ii. Is there any statistical relationship between number of microbreweries and annual per capita consumption of beer? A negative dependency can be supposed; this is typical for Belgium. Belgium is typical beer country, but the per capita consumption is half compering to the Czech Republic (Table 4), because typical beer for Belgium - Belgian abbey - is high-strength beer. Microbreweries usually brew special and high-strength beers, meaning that consumers drink smaller volumes of beer. Beer produced by microbreweries usually has higher added value and the Czech Republic has been the state with highest beer consumption per capita for many years.

iii. Is there any statistically significant relationship between number of microbreweries and beer market concentration? It can be supposed that the beer market operates in two ways; there is ever increasing market concentration in industrial breweries segment and this usually brings homogenization of the market, while on the other hand microbreweries bring heterogeneity. It can be supposed that generally high beer market concentration may be another source of Czech microbrewery competitiveness.

iv. Is there any statistically significant relationship between number of microbreweries and various 
beer market indicators (packaging, ${ }^{\circ}$ Plato). Increasing demand for stronger beer (higher degrees Plato) can have a positive impact on microbreweries competitiveness. The segment of microbreweries in the Czech Republic is still very tiny if it is measured by amount of produced bee (Figure 1). In last 10 years, the market share of microbreweries has increased 8 times, it can be supposed that the market indicator can be tightly linked with some other beer market indicators - variables. The problem is that there are not available data for the amount of top fermented beer - ale. In the Czech Republic many of microbreweries brew top fermented beer and some of them produce only top fermented beers.

v. Can models be produced to simulate the market? And using these equations, can one determine the conditions which will result in 400, 500 and 1000 microbreweries? Some Czech beer experts have the opinions, that in the nearby future can be in the Czech Republic 1000 (micro)breweries, similar situation was in in the end of $19^{\text {th }}$ century.

\section{Materials and methods}

The aims and research questions are addressed using the derived econometric model. The model specification is based on the neoclassical consumer theory and new industrial organization theory. Thus, the model explains the the number of microbreweries based on the three groups of variables, namely: demographic aspects, market concentration aspects and six selected market indicators (see relation (7)).

The variable specification is as follows. Two variables were chosen in regard to the demographic aspects of the first research question:

- Total population in the Czech Republic.

- Population within the age range 25 - 39 years. We can suppose that these consumers are the most important consumers for microbreweries. Young consumers (younger than 25 years) do not normally earn so much and as such they don't usually buy more expensive beer from microbreweries, and old consumers (older than 39) can be more conservative. Microbreweries very often produce less traditional kinds of beer (such as ales etc.), and as such conservative consumers do not normally frequent such institutions.
Four indicators were chosen for market concentration as explanatory variable:

\section{i. Herfindal-Hirshman index (HHI).}

$H H I$ is defined as the sum of the squared market shares of all the firms in the industry (Tremblay, V. J. et al., 2005). This indicator is very often used by various national and supranational authorities for solving mergers, acquisition etc.

The formula for its calculation is

$H H I=\sum_{1}^{i} y_{i}^{2}$,

where

$i=1,2, \ldots, \mathrm{n}$,

$y_{i}$ states for the market share of $i^{\text {th }}$ company (\%),

$n$ means number of operators in the sector.

\section{ii. Concentration Coefficient $\mathrm{CC} 3$}

The formula for its calculation is

CC $3=\sum_{1}^{j} y_{j}$,

where

$j=\langle 3\rangle$

$y_{j}$ states for the market share of $j^{\text {th }}$ company (\%), so this indicator describes market share of three biggest companies,

\section{iii. Concentration Coefficient $\mathrm{CC5}$}

The formula for its calculation is

CC5 $5=\sum_{1}^{k} y_{k}$,

where

$k=\langle 5\rangle$

$y_{k}$ states for the market share of $k^{\text {th }}$ company ( $\left.\%\right)$,

so this indicator describes market share of three biggest companies,

\section{iv. Gini Coefficient $G C$}

The Gini Coefficient is calculated on the basis of a Lorenz Curve. This curve describes cumulative percentages of market shares dependency (in ascending order) and cumulative percentages, if every operator has the same market share. The border of ideal equality is an ideal situation where all the operators in the sector have the same market share. As such, the Gini coefficient is the surface between the border of ideal equity and the Lorenz Curve. If we have the general form 
of the Lorenz Curve

$$
y_{l}=a^{b x} \text {. }
$$

So the surface between the Lorenz Curve and axis y in the interval $\langle 0 \% ; 100 \%\rangle$ is

$$
B=\int_{0}^{100} a e^{b x}=\frac{a}{b}\left(e^{100 b}-1\right) .
$$

And finally the formula for Gini Coefficient is

$$
G C=\frac{5000+100 a-\frac{a}{b}\left(e^{100 b}-1\right)}{5000} .
$$

Data in the form of time series is used for the modelling, with the data in annual sequences (1995 - 2015), meaning a total of 21 observations, see Table 5.

Thus the model is in this general form

$$
y=\underset{f}{\mathrm{f}\left(x_{2}, x_{3}, x_{4}, x_{5}, x_{6}, x_{7}, x_{8}, x_{9}, x_{10}, x_{11}, x_{12}, x_{13}, x_{14},\right.}
$$

And the declaration of variables is

$y$ number of operating microbreweries $x_{2}$ population of $25-39$ years age range (mil. inhabitants)

$x_{3} \quad$ total population (mil. inhabitants)

$x_{4}$ beer consumption per capita (1/year)

$x_{5} \quad H H I$

$x_{6} \quad C C 3(\%)$

$x_{7} \quad C C 5(\%)$

$x_{8} \quad G I$

$x_{9} \quad x_{2} / x_{3}$

$x_{10}$ proportion of domestic beer consumption in party barrels (\%)

$x_{11}$ proportion of domestic beer consumption in glasses $(\%)$

$x_{12}$ proportion of domestic beer consumption in plastic bottles $(\%)$

$x_{13}$ proportion of domestic beer consumption in cans $(\%)$

$x_{14}$ proportion of domestic beer consumption of beer $11-12.99^{\circ}$ Plato

\begin{tabular}{|c|c|c|c|c|c|c|c|c|c|c|c|c|c|c|c|}
\hline year & $y$ & $x_{2}$ & $x_{3}$ & $x_{4}$ & $x_{5}$ & $x_{6}$ & $x_{7}$ & $x_{8}$ & $x_{9}$ & $x_{10}$ & $x_{I 1}$ & $x_{12}$ & $x_{13}$ & $x_{14}$ & $x_{15}$ \\
\hline 1995 & 20 & 2.07 & 10.33 & 157 & 733 & 34.58 & 48.43 & 0.74 & 0.20 & 0.00 & 52.32 & 0.00 & 0.92 & 30.39 & 45.89 \\
\hline 1996 & 21 & 2.06 & 10.32 & 157 & 770 & 38.16 & 52.00 & 0.77 & 0.20 & 0.00 & 53.61 & 0.00 & 1.20 & 30.43 & 44.16 \\
\hline 1997 & 23 & 2.06 & 10.31 & 161 & 861 & 43.19 & 57.03 & 0.77 & 0.20 & 0.00 & 50.45 & 0.00 & 1.37 & 31.10 & 46.75 \\
\hline 1998 & 24 & 2.07 & 10.30 & 161 & 2374 & 58.55 & 68.10 & 0.69 & 0.20 & 0.00 & 48.98 & 0.00 & 1.63 & 29.98 & 48.09 \\
\hline 1999 & 27 & 2.12 & 10.29 & 160 & 2222 & 58.39 & 68.32 & 0.72 & 0.21 & 0.00 & 47.67 & 0.00 & 1.79 & 29.24 & 50.54 \\
\hline 2000 & 28 & 2.12 & 10.29 & 160 & 2176 & 58.03 & 67.89 & 0.69 & 0.21 & 0.06 & 45.67 & 0.00 & 1.89 & 29.27 & 50.32 \\
\hline 2001 & 33 & 2.25 & 10.27 & 157 & 2428 & 60.83 & 70.04 & 0.69 & 0.22 & 0.01 & 44.90 & 0.00 & 1.92 & 28.06 & 53.16 \\
\hline 2002 & 38 & 2.28 & 10.21 & 160 & 2588 & 62.45 & 71.24 & 0.80 & 0.22 & 0.02 & 43.54 & 0.48 & 1.94 & 28.45 & 54.01 \\
\hline 2003 & 39 & 2.33 & 10.20 & 162 & 2662 & 63.49 & 72.19 & 0.80 & 0.23 & 0.02 & 43.29 & 0.27 & 2.02 & 28.08 & 54.39 \\
\hline 2004 & 45 & 2.37 & 10.21 & 161 & 2616 & 63.37 & 71.96 & 0.80 & 0.23 & 0.02 & 43.72 & 0.34 & 2.16 & 28.14 & 53.76 \\
\hline 2005 & 49 & 2.40 & 10.22 & 164 & 2645 & 63.74 & 72.36 & 0.80 & 0.23 & 0.03 & 44.10 & 0.29 & 2.26 & 27.86 & 53.33 \\
\hline 2006 & 59 & 2.42 & 10.25 & 159 & 2723 & 64.72 & 73.29 & 0.78 & 0.24 & 0.02 & 44.89 & 0.05 & 2.60 & 29.15 & 52.44 \\
\hline 2007 & 68 & 2.44 & 10.29 & 159 & 2760 & 65.09 & 73.78 & 0.76 & 0.24 & 0.01 & 45.87 & 0.14 & 2.61 & 29.82 & 51.37 \\
\hline 2008 & 74 & 2.48 & 10.38 & 157 & 2790 & 72.06 & 81.15 & 0.78 & 0.24 & 0.03 & 46.58 & 0.05 & 2.78 & 31.10 & 50.57 \\
\hline 2009 & 79 & 2.52 & 10.47 & 151 & 2710 & 71.48 & 79.85 & 0.75 & 0.24 & 0.11 & 53.56 & 1.31 & 3.01 & 32.61 & 49.39 \\
\hline 2010 & 96 & 2.53 & 10.51 & 144 & 2420 & 68.84 & 77.48 & 0.79 & 0.24 & 0.12 & 46.00 & 2.80 & 3.14 & 36.76 & 47.94 \\
\hline 2011 & 120 & 2.53 & 10.53 & 143 & 2400 & 70.93 & 80.71 & 0.80 & 0.24 & 0.12 & 44.31 & 5.78 & 3.63 & 37.71 & 46.14 \\
\hline 2012 & 143 & 2.49 & 10.51 & 149 & 2410 & 69.86 & 79.76 & 0.88 & 0.24 & 0.10 & 41.98 & 10.25 & 4.19 & 38.05 & 43.48 \\
\hline 2013 & 192 & 2.46 & 10.52 & 147 & 2450 & 65.25 & 74.34 & 0.89 & 0.23 & 0.08 & 41.91 & 11.24 & 3.86 & 38.86 & 42.91 \\
\hline 2014 & 232 & 2.42 & 10.51 & 147 & 2475 & 67.73 & 76.98 & 0.90 & 0.23 & 0.08 & 40.96 & 12.35 & 4.41 & 41.49 & 42.20 \\
\hline 2015 & 289 & 2.39 & 10.55 & 145 & 2352 & 69.84 & 80.08 & 0.91 & 0.23 & 0.08 & 40.86 & 11.99 & 5.62 & 43.24 & 41.45 \\
\hline
\end{tabular}

$x_{15}$ proportion of domestic beer consumption in barrels (KEGs) and tanks (\%)

We can suppose with a high level of probability that some variables from the economic model are not

Sources: Czech Statistical Office, Czech Beer and Malt Association, Customs Administration of the Czech Republic

Table 5: Data set used for the estimation. 
statistically significant, including multicollinearity etc. This aspect is discussed and dealt with in the next chapter.

The regression dependency is calculated for linear function and power function and the Gretl SW was used for the estimation.

\section{Results and discussion}

The only microbrewery which survived the communist era and was founded before 1991 is Microbrewery U Fleků in Prague. This brewery is historically an old brewing privilege holder. This law was introduced by King Wenceslas II. $(1278-1305)$, and their old brewing privilege has never been officially canceled.

Figure 3 shows the evolution of microbreweries in the Czech Republic since 1991. In order to create the graph, various information (mainly from the internet) was used. In the Czech Republic, there is no official database of microbreweries which is managed by any state authority.

The very first microbrewery in the Czech Republic was Meloun (named after founder Milan Meloun), which opened in 1991. It was a family business. Production ceased in 1998, because of the sudden death of Meloun (personal interview with his granddaughter). He was the only one who was involved in beer distribution and nobody else in the family knew the distribution channels. This microbrewery was not a typical microbrewery, because more than half of production was consumed beyond its own restaurant.

The oldest microbrewery which has survived to the present (except U Fleků) is Pivovarský dvůr Chýně near Prague, which was founded in 1992. In Figure 3, we can see that the number of breweries operating has grown exponentially.

Many of the 15 explanatory variables are redundant, so they should be reduced. The highest pair correlation was detected between the variables $x_{6}$ $(C C 3(\%))$ and $x_{7}(C C 5(\%))$. For linear dependency, the correlation is 0.9955 , for power function the value is 0.9948 . As such we should choose only one variable for describing market concentration. The situation is very similar for the variables which describe the types of packages.

So by the gradual eliminations of (redundant) explanatory variables we estimated the two models. The criteria for elimination is a statistical significance of every particular variable and multicollinearity. Model 1 is a linear model and Model 2 is a model in nonlinear (power) form.

\section{Econometric verification}

- We can exclude the problem with autocorrelation for both regressions because the DW-values are in the range $\left\langle 1.40823^{2} ; 2\right\rangle$, or more specifically we can say that there is not a statistically significant autorrelation.

- According to the White and Breusch-Pagan tests, heteroscedasticity was not detected for linear regression nor for power regression.

- According to the Jarque-Bera test the residuas have normal distribution.

A very strong relationship between all the chosen phenomena is confirmed. Thus according to both

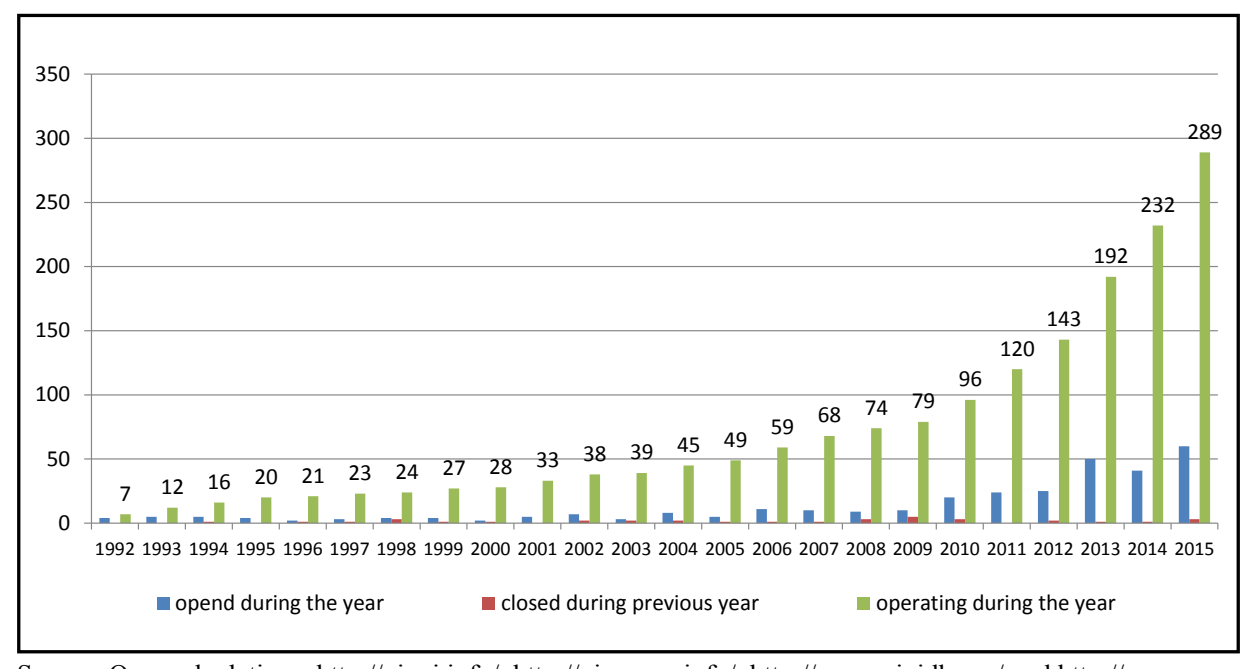

Source: Own calculations, http://pivni.info/, http://pivovary.info/, http://www.pividky.cz/ and http://www. minipivo.cz/

Figure 3: Microbrewery evolution in the Czech Republic. 


\begin{tabular}{|c|c|c|c|c|c|}
\hline & Coefficient & Std. Error & t-ratio & $\mathrm{p}$-value & \\
\hline const & -1.217 & 81.2976 & -0.0150 & 0.98823 & \\
\hline $\mathrm{x}_{8}$ & 254.26 & 84.9976 & 2.9914 & 0.00820 & $* * *$ \\
\hline$x_{9}$ & -1219.51 & 280.075 & -4.3542 & 0.00043 & $* * *$ \\
\hline $\mathrm{x}_{13}$ & 59.6018 & 5.25418 & 11.3437 & $<0.00001$ & $* * *$ \\
\hline Mean dependent var & \multicolumn{2}{|c|}{80.90476} & S.D. dependent var & \multicolumn{2}{|c|}{75.02593} \\
\hline Sum squared resid & \multicolumn{2}{|c|}{3845.814} & S.E. of regression & \multicolumn{2}{|c|}{15.04076} \\
\hline R-squared & \multicolumn{2}{|c|}{0.965839} & Adjusted R-squared & \multicolumn{2}{|c|}{0.959810} \\
\hline $\mathrm{F}(3,17)$ & \multicolumn{2}{|c|}{160.2126} & P-value(F) & \multicolumn{2}{|c|}{$1.16 \mathrm{e}-12$} \\
\hline Log-likelihood & \multicolumn{2}{|c|}{-84.50500} & Akaike criterion & \multicolumn{2}{|c|}{177.0100} \\
\hline Schwarz criterion & \multicolumn{2}{|c|}{181.1881} & Hannan-Quinn & \multicolumn{2}{|c|}{177.9168} \\
\hline rho & \multicolumn{2}{|c|}{-0.054036} & Durbin-Watson & \multicolumn{2}{|c|}{1.979351} \\
\hline p-value White & \multicolumn{2}{|c|}{0.090682} & p-value Jargue - Bera & \multicolumn{2}{|c|}{0.01309} \\
\hline
\end{tabular}

Source: Own calculation in Gretl

Model 1 (linear): OLS, using observations 1995-2015 ( $\mathrm{T}=21)$.

\begin{tabular}{|c|c|c|c|c|c|}
\hline & Coefficient & Std. Error & t-ratio & $p$-value & \\
\hline const & 13.2349 & 1.92937 & 6.8597 & $<0.00001$ & \\
\hline$x_{6}$ & -1.94305 & 0.286841 & -6.7740 & $<0.00001$ & $* * *$ \\
\hline$x_{9}$ & 2.09279 & 0.703408 & 2.9752 & 0.00849 & $* * *$ \\
\hline$x_{13}$ & 2.21634 & 0.113257 & 19.5691 & $<0.00001$ & $* * *$ \\
\hline Mean dependent var & \multicolumn{2}{|c|}{4.053994} & S.D. dependent var & \multicolumn{2}{|c|}{0.817689} \\
\hline Sum squared resid & \multicolumn{2}{|c|}{0.251542} & S.E. of regression & \multicolumn{2}{|c|}{0.121641} \\
\hline R-squared & \multicolumn{2}{|c|}{0.981189} & Adjusted R-squared & \multicolumn{2}{|c|}{0.977870} \\
\hline $\mathrm{F}(3,17)$ & \multicolumn{2}{|c|}{295.5808} & P-value(F) & \multicolumn{2}{|c|}{$7.32 \mathrm{e}-15$} \\
\hline Log-likelihood & \multicolumn{2}{|c|}{16.66129} & Akaike criterion & \multicolumn{2}{|c|}{-25.32258} \\
\hline Schwarz criterion & \multicolumn{2}{|c|}{-21.14449} & Hannan-Quinn & \multicolumn{2}{|c|}{-24.41583} \\
\hline rho & \multicolumn{2}{|c|}{-0.063016} & Durbin-Watson & \multicolumn{2}{|c|}{1.982014} \\
\hline p-value White & \multicolumn{2}{|c|}{0.141034} & p-value Jargue - Bera & \multicolumn{2}{|c|}{0.57705} \\
\hline
\end{tabular}

Source: Own calculation in Gretl

Model 2 (power): OLS, using observations 1995-2015 (T=21).

models the number of operating companies depends on

i. Market concentration;

ii. Proportion of $25-39$ year olds in the total Czech population;

iii. Proportion of domestic beer consumption in cans $(\%)$.

So the analytical forms of the equations are:

Linear:

$y=-1.217+254.26 x_{8}-1219.51 x_{9}+59.6018 x_{13}+u$

Power:

$y=559556.6205 \mathrm{x}_{6}^{-1.94305} x_{9}^{2.09279} x_{13}^{2.21634}+u$

In this form, a comparison of both results is not possible, instead one has to count the values of elasticities for the linear equation. The elasticities for both models are clearly given in Table 6 .

\begin{tabular}{|l|c|c|c|c|}
\hline & \multicolumn{2}{|c|}{ Linear dependency } & \multicolumn{2}{c|}{ Power dependency } \\
\hline & variable & elasticity & variable & elasticity \\
\hline Market concentration & $x_{8}$ & 2.47 & $x_{6}$ & -1.94 \\
\hline Population rate & $x_{9}$ & -3.38 & $x_{9}$ & 2.09 \\
\hline Consumption in cans & $x_{13}$ & 1.93 & $x_{13}$ & 2.22 \\
\hline
\end{tabular}

Source: Own calculation

Table 6: Values of elasticities for linear and power dependency.

The results show that all the values of elasticities (in absolute value) are considerably high. The primary assumptions are valid for both equations only for the variable $x_{13}$, i.e. the rate of beer consumed in cans. A particularly surprising result is that the market concentration indicator $\left(x_{6}\right)$ has negative elasticity for the power function, and an economic interpretation of this is that 
if the market concentration (indicator CC3) increases by $1 \%$, then the number of microbreweries decreases by $1.94 \%$. The reason for this value may be the decrease in market concentration since 2008 . In this year, the three most powerful companies controlled $72.06 \%$ of the Czech beer market, while two years later this figure was only $68 \%$ and the number of microbreweries had increased by $30 \%$. But we should highlight that two different variables were used for the market concentration indicator; $G C$ was used for linear dependency, and $C C 3$ was used for power dependency (according to the statistical characteristics and verification of both models).

The condition for the primary assumption about demography was met only for a power function, where the influence is positive. For a linear function, the condition is negative. The demography indicator is the proportion of $25-39$ years old in the total Czech population. The influence is ambiguous; while the number of microbreweries increased in the whole period $(1995$ - 2015), the value of the demographic indicator increased in the period 1995 - 2010, but decreased from 2011. The maximum rate was in 2011 at $24.1 \%$.

The only assumption which is in agreement with the results is beer consumption in cans $\left(x_{13}\right)$. The elasticities are pretty similar for both equations, for a linear function it is $1.93 \%$ and for a power function it is $2.22 \%$.

We can do a simulation for both regressions. The endogenous variable (number of microbreweries) does not influence exogenous variables. The microbreweries do not produce beer in cans, the microbreweries cannot influence the population rate and because they had in the year 2015 total market share $1.7 \%$ (289 companies), so they cannot influence the beer market concentration. The results are given in the Table 7 .

The simulations were calculated for 400, 500 and 1000 microbreweries, ceteris paribus. Some results are not in line with assumptions according to the previous analysis. The problem may be that the microbrewery sector in the Czech Republic is very young and the microbrewery boom (wave) is very strong, such that it is very difficult to do any simulation in these conditions.

The simulation results for market concentration for linear dependency do not make any sense, as the market concentration $(G C)$ can't be higher than 1. The population rate (for 1000 microbreweries) does not make any sense either, because it is a negative number.

The only acceptable results of the simulation are population rate for the power function, and share of beer consumed in cans for both functions.

\section{Conclusion}

Development of the Czech microbrewery sector is very similar to that in western states, except with a $10-15$ years delay because of the communist regime. While the first microbrewery in USA was opened in 1976, in the Czech Republic (specifically in Czechoslovakia) the first microbrewery was opened in 1991. To understand the microbrewery boom in the Czech Republic one must go back to the situation after the Second World War, specifically the situation in 1948, when the communists carried out their coup d'état. The number of Czech breweries at the time was very similar to that in neighbouring Bavaria. Both beer markets were heterogeneous (there was no homogenous beer product) and both markets were fragmented, with very low market concentration. But subsequent to 1948 , a forced concentration process was started, mainly involving small industrial breweries with annual production of less than $10000 \mathrm{hl}$, which were closed by the communists. Product homogenization processes also took place. Development in Bavaria from 1948 was completely different; product homogeneity was kept at a similar level and the $\mathrm{HH}$ index is still very low. The $\mathrm{HH}$ index is no more than 800 points for the whole of Germany (Adams, 2006). This is also very important for the successful microbrewery boom in the Czech Republic. Over

\begin{tabular}{|l|c|c|c|c|c|c|c|c|}
\hline \multirow{2}{*}{ indicator } & \multicolumn{4}{|c|}{ linear } & \multicolumn{4}{|c|}{ power } \\
\cline { 2 - 6 } & \multirow{2}{*}{ variable } & \multicolumn{2}{|c|}{ no. of microbreweries (y) } & \multirow{2}{*}{ variable } & \multicolumn{3}{c|}{ no. of microbreweries (y) } \\
\cline { 3 - 7 } \cline { 7 - 9 } & & 400 & 500 & 1000 & & 400 & 500 & 1000 \\
\hline Market concentration & $x_{8}$ & 1.35 & 1.74 & 3.71 & $x_{6}$ & 60.18 & 53.65 & 37.55 \\
\hline Population rate & $x_{9}$ & 0.14 & 0.05 & -0.36 & $x_{9}$ & 0.26 & 0.29 & 0.40 \\
\hline Consumption in cans & $x_{13}$ & 7.48 & 9.16 & 17.55 & $x_{13}$ & 6.40 & 7.08 & 9.68 \\
\hline
\end{tabular}

Source: Own calculation of the basis of equations

Table 7: Results of the simulations. 
the period 1991 - 2015, the Czech Republic started slowly but surely to return to the previous situation and tradition which had been interrupted in the $1948-1989$ period.

The answers to the all five research questions are mostly difficult and mostly ambiguous. The statistical significance between beer market concentration and number of microbreweries was strongly proven. But the direction of influence is very ambiguous; on the basis of both above mentioned models it is not possible to make unequivocal results. The reason for this may be that with the economic crisis (2008/2009) the fall in the market share of the Czech beer market's leading company was of greatest importance. The market share of this company decreased from $49 \%$ to $43 \%$. A fairly similar process was characteristic of almost all major Czech brewing companies. While before 2008 the number of microbreweries had increased fairly slowly, since 2009 the number of microbreweries has been growing exponentially. Danson et al. (2015) came to the conclusion in the UK context that, while there are particular challenges to starting a microbrewery, barriers to entry are lower than for many other sectors. In terms of the food and beverage industry, different conditions can be seen for example in sugar beet processing. New processors have no chance of penetrating the EU market (Rezbová et al., 2014). We can suppose that conditions in the Czech Republic may be similar to those for microbreweries like in UK. The microbrewery boom in the $21^{\text {st }}$ century in the Czech Republic is more a question of the demand side than the supply side. Technical efficiency in the food processing industry did not change significantly within the period from 2000 to 2007 (Čechura, 2009).

Similarly controversial is the influence of demographic aspects - the proportion of the population $25-39$ years of age. It can be supposed that this generation have enough money for more expensive beer from microbreweries compared to younger consumers, and on the other hand this generation is not as conservative as older generations. In the above mentioned part of this text we state that in general Czech beer consumers are very conservative. For a linear dependency the influence is negative, while for power function it is positive. Similarly to the case of market share concentration, there is a critical point in this case too. The proportion of above mentioned generation in the whole population grew until 2010, but since 2011 the proportion of this generation has been decreasing. We can make the statement that before reaching this demographical peak (a similar period to the growth of beer market concentration) this variable had influenced the number of microbreweries in an unequivocally positive manner. Since reaching this peak, the microbrewery boom has become a society-wide phenomenon.

The influence of per capita beer consumption for both models is not statistically significant. As in the case of the above mentioned variables, per capita beer consumption until 2008 was extremely stabile. In the period $1995-2008$ the differences between annual values and mean value (159.55) was no higher than $2.5 \%$ (this was the value in 2005). With the economic crisis, a beer consumption decrease was identified. The average value for the period $2009-2015$ is $8.2 \%$ lower than the period $1995-2008$.

There is not more statistical data on the production volume of various kinds of beer, because the beer microbreweries very often focus on is not mainstream beer. It would be very interesting to analyze the relationship between the microbrewery boom and the production of non-filtrated beer, ales etc. According to the available data, there is no relation between beer original gravity and number of microbreweries; for describing beer original gravity, the proportion of $11-12.99^{\circ}$ Plato beer compared to total production was used. The only statistically significant variable which influenced the number of microbreweries is the share of beer sold in metal cans. This is related to market change, with consumers visiting ordinary pubs and restaurants less, and considering more deeply the decision about which restaurant (or brewpub) to visit, and they buy more beer in cans. The same development was seen in the US market.

Furthmore, it is indisputable that a very significant source of the Czech microbrewery boom and competitiveness is the economic crisis and the limited ability of industrial breweries to respond to consumer demand adequately and in time. Negative aspects can also be seen, however. Operations which offer only in-house brewed beers and ales can fall victim to the same market trap of limited variety of offerings that has troubled the large brewers (Murray and O'Neill 2012).

\section{Acknowledgements}

The findings presented in this paper have arisen from research enabled by the grant of the Internal Grant Agency provided 
by the Faculty of Economics and Management, Czech University of Life Sciences in Prague - no. 20151049.
This article is dedicated to Milan Meloun (1951 - 1998), who founded the first microbrewery in the Czech Republic after the communist era.

Corresponding author:

Ing. Tomáš Maier, Ph.D.

Czech University of Life Sciences Prague, Kamýcká 129, Prague 6, 165 21, Czech Republic

Phone: +420 224382 133, email: maiert@pef.czu.cz

\section{References}

[1] Adams, V. J. (2006) „Markets - Beer in Germany and the United States“, Journal of Economic Perspectives, Vol. 20, No. 1, pp. 189 - 205. ISSN 0895-3309. DOI 10.1257/089533006776526120.

[2] Backus, R. (1999) "Business as usual is over": An interview with brewing industry analyst Robert S. Weinberg", New Brewer, Vol. 15, No. 2, pp. 27 - 43.

[3] Behre, K. E. (1998) „The history of beer additives in Europe - a review“, Vegetation History and Archaeobotany, Vol. 8, No. 1-2, pp. 35 - 48. ISSN 0939-6314. DOI 10.1007/BF02042841.

[4] Boston Beer Company, Inc. (2016) „Annual Report 2015“. Boston Beer Company, Inc., March 2016. [Online]. Available: phx.corporate-ir.net/External.File?item=U GFyZW50SUQ9MzMyNDczfENoaWxkSUQ9LTF8VHlwZT0z\&t=1\&cb=635961502985673773 [Accessed: 25 Apr. 2016].

[5] Bower, J. and Cox, H. (2012). „How Scottish \& Newcastle became the U.K.'s largest brewer: A case of regulatory capture?"“, Business History Review, Vol. 86, No. 1, pp. 43-68. ISSN 0007-6805. DOI $10.1017 / \mathrm{S} 0007680512000037$.

[6] Brewers of Europe (2015) "Beer Statistics 2015 Edition", Marilies Van de Walle, ISBN 978-29601382-5-2.

[7] Brewers Association (2016) „Draft Beer Industry Market Segments“. Brewers Association, 2016. [Online]. Available: https://www.brewersassociation.org/statistics/market-segments/ [Accessed: 25 Apr. 2016].

[8] Brewers Association (2016) „Number of Breweries“. Brewers Association, 2016. [Online]. Available: https://www.brewersassociation.org/statistics/number-of-breweries/ [Accessed: 25 Apr. 2016].

[9] Carroll, G., R. and Swaminathan, A. (2000) „Why the Microbrewery Movement? Organizational Dynamics of Resource Partitioning in the U.S. Brewing Industry“, American Journal of Sociology, Vol. 106, No. 3, pp. 715 - 762. ISSN 0002-9602. DOI 10.1086/318962.

[10] Castiglione, C., Grochová, L., Infante, D. and Smirnova, J. (2011) "The demand for beer in presence of past consumption and advertising in the Czech Republic", Agricultural Economics, Vol. 57, No. 12, pp. 589 - 599. ISSN 0139-570X.

[11] Czech Statistical Office (2016), External Trade Database“. Czech Statistical Office, 2016. [Online]. Available: http://apl.czso.cz/pll/stazo/STAZO.STAZO?jazyk=EN\&prvni=N [[Accessed: 25 Apr. 2016].

[12] Customs Adminstration of the Czech Republic (2011 - 2016) „Beer - the Quantity Put in Free Tax Circulation 2006 - 2015“. Customs Adminstration of the Czech Republic, March 2016. [Online]. Available: https:/www.celnisprava.cz/cz/dane/statistiky/Stranky/pivo.aspx [Accessed: 25 Apr. 2016].

[13] Czech Beer and Malt Association (1995 - 2015) „Statistical Guides“. Czech Beer and Malt Association.

[14] Čechura, L. (2009) "Zdroje a limity růstu agrárního sektoru - Analýza efektivnosti a produktivity českého agrárního sektoru: aplikace SFA (Stochastic Frontier Analysis)", $1^{\text {st }}$ ed. Prague: Wolters Kluwer ČR, p. 296. ISBN 978-80-7357-493-2. 
[15] Danson, M., Galloway, L., Cabras, I. and Beatty, T. (2015) „Microbrewing and entrepreneurship: The origins, development and integration of real ale breweries in the UK", International Journal of Entrepreneurship and Innovation, Vol 16, No. 2, pp. 135 - 144. ISSN 14657503. DOI 10.5367/ijei.2015.0183.

[16] Ellis, V. and Bosworth, G. (2015) "Supporting rural entrepreneurship in the UK microbrewery sector", British Food Journal, Vol. 117, No. 11, pp. 2724 - 2738. ISSN 0007070X. DOI 10.1108/BFJ-12-2014-0412.

[17] Kirkby, D. (2003) „“Beer, glorious beer”: gender politics and Australian popular culture“, Journal of Popular Culture, Vol 37, No. 2, pp. 244 - 256. ISSN 1540-5931. DOI 10.1111/1540-5931.00066.

[18] Kryl, P., Gregor, T. and Los, J. (2012) "Comparison of analytical parameters of beer brewed in two different technological ways at two pub breweries", Acta Universitatis Agriculturae et Silviculturae Mendelianae Brunensis, Vol. 60, No. 5, pp. 137 - 144. ISSN 12118516.

[19] Maye, D. (2012) „Real ALE microbrewing and relations of trust: A commodity chain perspective“, Tijdschrift voor economische en sociale geografie, Vol. 103, No. 4, pp. 473 - 486. ISSN 0040747X. DOI 10.1111/j.1467-9663.2012.00716.x.

[20] Murray, D. W. and O'Neill, M. A. (2012) "Craft beer: Penetrating a niche market", British Food Journal, Vol. 114, No. 7, pp. 899 - 909. ISSN 0007070X. DOI 10.1108/00070701211241518.

[21] McAllister, P. (2003) „Culture, practice, and the semantics of Xhosa beer-drinking“, Ethnology, Vol. 42, No. 3, pp. 187 - 207. ISSN 2160-3510.

[22] McAllister, P. A. (2006) „Xhosa beer drinking rituals: power, practice and performance in the South African rural periphery“ In: Ritual Studies Monograph Series, Carolina Academic Press, Durham. 355 p. ISBN 0890890218.

[23] Porter, M. E. (1980) "Competitive Strategy: Techniques for Analyzing Industries and Competitors". New York: Free Press.

[24] Rezbova, H. Smutka, L. Pulkrabek, J. Benesova, I. (2014) „European Sugar factories, Sugar Companies and their Alliances: Who is in Control of European Sugar Market?", Listy cukrovarnicke a reparske, Vol 130, No. 11, pp. 365 - 369. ISSN 1210-3306.

[25] Sandberg, P. (2010) „The creation of big business in the Swedish brewing industry during the aftermath of the Second World War", Scandinavian Economic History Review, Vol. 58, No. 1, pp. 43 - 59. ISSN 0358-5522. DOI 10.1080/03585520903516353.

[26] Statista, Inc. (2016) „Per capita beer consumption worldwide in 2014, by leading countries (in liters)“. Statista, Inc., 2016. [Online]. Available: http://www.statista.com/statistics/382040/ global-per-capita-beer-consumption-by-country/ [Accessed: 25 Apr. 2016].

[27] Statista, Inc. (2016), ,Per capita consumption of beer in the United States from 2010 to 2014 (in gallons)“. Statista, Inc., 2016. [Online]. Available: http://www.statista.com/statistics/382074/usper-capita-beer-consumption/ [Accessed: 25 Apr. 2016].

[28] Strizencova, M. (2014) „Particular Business Possibilities for Small Breweries“ in Majtan, S.: Aktuálne problémy podnikovej sfery 2014. University of Economics in Bratislava, May. 2014. [Online]. Available: http://fpm.euba.sk/userdata/adivincova/Stefan_Majtan_a_kolektiv_Aktualne_ problemy_podnikovej_sfery_2014_copy.pdf [Accessed: 25 Apr. 2016].

[29] Swiss Customs Administration. (2016) „Swiss beer market: statistical data“. Swiss Customs Administration", Feb. 2016. [Online]. http://www.ezv.admin.ch/zollinfo firmen/04020/04256/04259/04517/05444/index.html?lang=en\&download=NHzLpZeg7t, lnp6I0NTU04212Z61n1ad1IZn4Z2qZpnO2Yuq2Z6gpJCDfIF5e2ym162epYbg2c_JjKbNoKSn6A-[Accessed: 25 Apr. 2016].

[30] Tremblay, V. J., Iwasaki, N. and Tremblay, C. H (2005) „The dynamics of industry concentration for U.S. micro and macro brewers“, Review of Industrial Organization, Vol 26, No. 3, pp. 307 - 324. ISSN 0889-938. DOI 10.1007/s11151-004-8114-9. 
[31] Wells, P. (2016) „Economies of Scale Versus Small Is Beautiful: A Business Model Approach Based on Architecture, Principles and Components in the Beer Industry“, Organization \& Environment, Vol. 29, No. 1, pp. 36 - 51. ISSN 1086-0266. DOI 10.1177/1086026615590882.

[32] World Bank. (2016) „Population 2014“. World Bank, Apr. 2016. [Online]. Available: http://databank.worldbank.org/data/download/POP.pdf [Accessed: 25 Apr. 2016]. 